\title{
The Declining Middle Zone Aquifer of the Southwestern Chad Basin in the last Millenium.
}

\author{
${ }^{1}$ A. K. Yusuf, I. B. Goni ${ }^{2}$, M. Hassan ${ }^{3}$ \\ 1Centre For Arid Zone Studies, University of Maiduguri. \\ ${ }^{2}$ Department of Geology, University of Maiduguri \\ ${ }^{3}$ Department of Physics, University of Maiduguri
}

\begin{abstract}
The Middle zone aquifer is the most extensive and most widely exploited of the three well known aquifers of the Chad Formation. This aquifer is confined by variable thickness of argillaceous deposits of $100-$ $150 \mathrm{~m}$ thick. This led to the variable heads in boreholes drilled to this zone. Boreholes drilled from 1960 to 2010 shows a drastic decline in piezometric heads. The piezometric heads of over $20 \mathrm{~m}$ above ground level (agl) observed in 1960 to $1.2 \mathrm{~m}$ agl in 2010 have declined over the last half century. In the present work the heads at $0.2 \mathrm{~m} /$ year giving the present piezometric head at an average of $0.5 \mathrm{~m}$ agl. The lower heads in old boreholes are attributed due to siltation, encrustation and ageing of borehole. Furthermore, lack of present day recharge and poor borehole construction methods play a vital role in determining the piezometric head.
\end{abstract}

Keywords: Aquifer, Declined, Piezometric head, Borehole, Encrustation.

\section{Introduction}

Groundwater in the Southwestern Chad Basin occurs in the Quaternary Chad Formation. Hydrogeologically it is the most prolific stratigraphic unit in the Basin. Groundwater in this deposit occurs under both confined and unconfined conditions. Three aquiferous zones have been clearly demarcated and named by Barber ad Jones (1960), as the Upper, Middle and Lower aquifers. The Upper aquifer generally unconfined and semi - confined, while the Middle and Lower Aquifers are confined. The Middle zone aquifer is the most extensive and most exploited of the zones. Because of thick clay (in some places over 100m), boreholes drilled to this zone yield artesian flow with piezometic head as high as $20 \mathrm{~m}$ above ground level. This positive head has significantly decline over the past half a century. The reason for this has been due to over abstraction largely due to the uncontrolled discharge from artesian wells and lack of replenishments. Several authors attempt to estimate the rate of decline in the piezometric head of the Middle zone aquifer for different periods of time. (Offodile, 1972, Adefila, 1975; Oteze and Fayose, 1988, Ndubisi, 1990, Oluboye, 1995, Goni et al; 2000 etc) estimated the rate of decline in piezometric head of the Middle zone aquifer boreholes and also the variability in head observed in boreholes drilled to the Middle zone aquifer, is the focus of this paper.

\section{Previous work.}

In 1934, Raeburn and Jones published an account of the Geology and Hydrogeology of the Nigerian part of the basin. Then followed by Barber and Jones (1960) who, in their study of the Geology and Hydrology of Maiduguri, recognized three zones of aquifers named the Upper, Middle and Lower zones. Miller, Johnson, Olowu and Uzoma (1966) published an account of the availability of groundwater in the Chad Basin of Bornu and Dikwa Emirates. In 1968, Miller and others published the result of further studies on the groundwater hydrology of the Chad Basin in the Emirates.

\section{Hydrogeology}

The Middle aquifer is confined by a clay layer up to $100 \mathrm{~m}$ thick in some places, with pressure sufficient to cause artesian flow. It is arenaceous in nature and stores water and termed Middle zone aquifer (Barber and Jones, 1960).Because of the heterogeneity of the aquifer materials, there is variability in hydraulic properties. Miller et al (1968) gave the following hydraulic parameters: Hydraulic conductivity range from $0.0000428-0.000179 \mathrm{~m} / \mathrm{sec}\left(90-380\right.$ gpd per square foot); transmissivity $0.000818-0.1141 \mathrm{~m}^{2} / \mathrm{sec}(520-$ 72,500 gpd per foot; storage coefficient $0.000014-0.00018$. They further subdivide the aquifer into six based on water yielding capability.

\subsection{SCOPE OF STUDY}

The study area is the Middle zone aquifer of the Nigerian sector of the Chad Basin. The area falls within latitude $11^{\circ} 30^{\prime} \mathrm{N}$ and $13^{\circ} 30^{\prime} \mathrm{N}$ and longitude $12^{\circ} 00^{\prime} \mathrm{E}$ and $14^{\circ} 30^{\prime} \mathrm{E}$. 


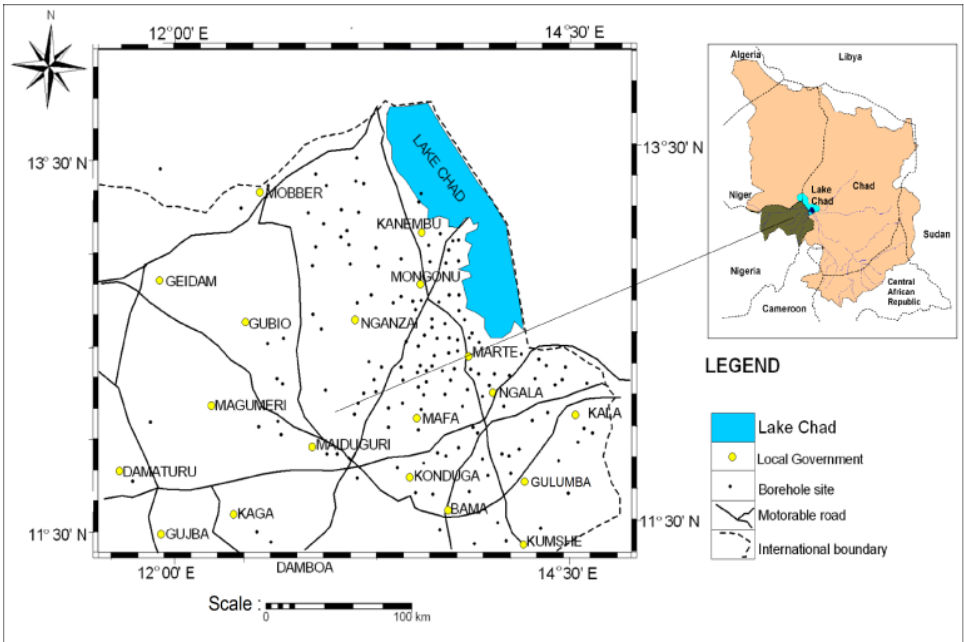

Fig.1: Map of the study area with Middle zone aquifer boreholes sampling sites.

Furthermore, Recharge Estimation (qualitatively) was carried out where the Middle aquifer is suspected to have outcropped or merged with the Upper aquifer, boreholes in that area was monitored for a period of 12 months using groundwater level fluctuation method. This method is chosen because a water level rise is the clearest indicator of recharge if all abstraction remains unchanged and atmospheric pressure effects can be ruled out.

The static water level (SWL) of seventy one Middle zone aquifer boreholes were monitored from February, 2010 to January, 2011 by the use of water level indicator as earlier used by researcher across the study area. These boreholes were drilled in 1960's - 2010's were analysed to determine the rate of decline over the last half century. The SWL of each borehole is measured once in a month.

The Middle zone aquifer is the most extensive and widely exploited of all the zones, extending to Republics of Niger, Cameroon and Chad. Because of the thick clay Formation (in some places over 100m), boreholes drilled to this zone yield artesian flow with piezometric head as high as $20 \mathrm{~m}$ agl. This positive head has significantly decline over the past half century. The reason for this has been due to over abstraction largely due to the uncontrolled discharge from the artesian wells and lack of or little replenishments (Adefila, 1975, BRGM, 1993).

The pressure heads are falling drastically due to indiscriminate and uncontrolled exploitation of the aquifer. There is still a noticeable decline in pressure surface of the free-flowing artesian wells in the Nigerian sector of the Chad Basin and consequently a shift in the limit of artesian flow in the pressure water of the Middle zone aquifer of the Chad Basin area eastward towards the lake with about $23 \mathrm{~km}$ for the last half a century (fig.2).

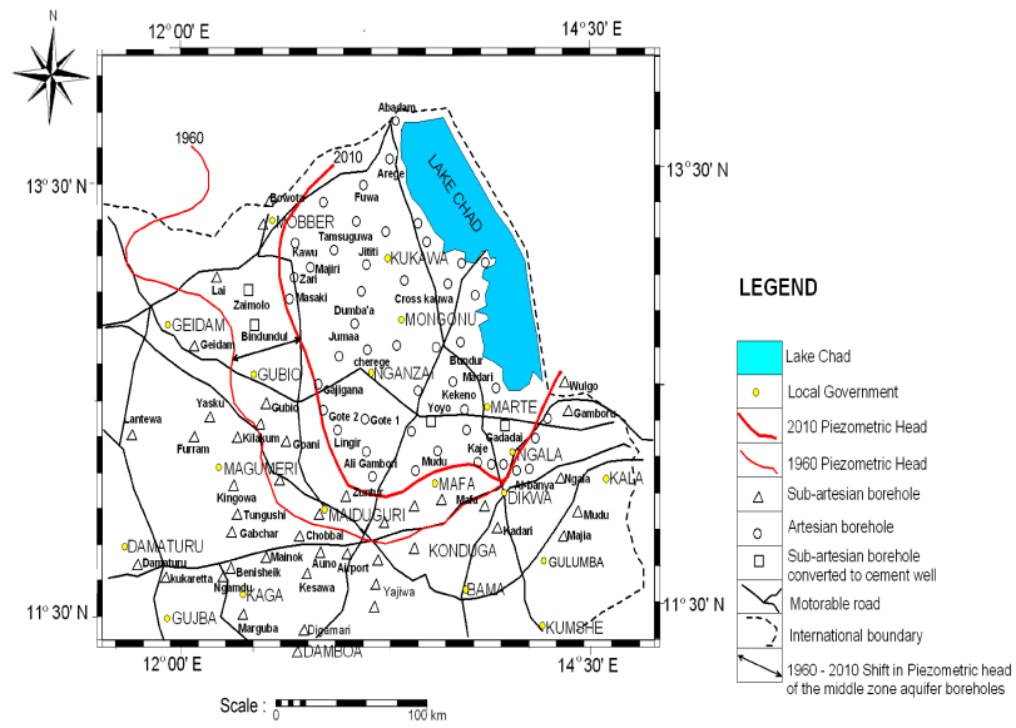

Fig.2. Piezometric Head Declines from 1960 - 2010. 


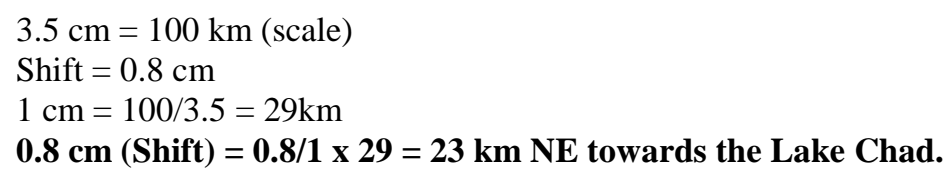

The increase in social and economic development in the area has brought about a sharp increase in groundwater exploitation resulting in the decline of the piezometric head of the Middle zone aquifer (Oteze and Fayose, 1988).

The boreholes drilled to the Middle zone in the 1960 yield artesian flow in Maiduguri with a piezometric head of over $8 \mathrm{~m}$ agl while in the 2010 boreholes piezometric head of $34 \mathrm{~m} \mathrm{bgl} \mathrm{was} \mathrm{recorded} \mathrm{in}$ Maiduguri. Furthermore, the artesian wells are now mostly found in the north of Maiduguri towards the Lake Chad. The closest artesian well to Maiduguri is in Zuntur village in Nganzai local government area of Borno State which is about $27 \mathrm{Km}$ northeast of Maiduguri (by road).However, from the above calculations an estimated shift of $23 \mathrm{Km}$ northeastwards towards the Lake is made for the past half a century.

The pressure heads are falling drastically due to indiscriminate and uncontrolled exploitation of the aquifer. There is still a noticeable decline in pressure surface of the free-flowing artesian wells in the Nigerian sector of the Chad Basin and consequently a shift in the limit of artesian flow in the pressure water of the Middle zone aquifer of the Chad Basin area eastward towards the lake with about $23 \mathrm{~km}$ for the last half a century (Fig.2.).

The water demand has dramatically increased over the last few decades, due to population growth and changes in life style of the people occasioned by modernization. This has brought about a sharp increase in groundwater exploitation resulting in the decline of the piezometric head of the Middle zone aquifer (Goni et al, 2000).

Table 1: The Decline of Piezometric Head of Middle Zone Aquifer Boreholes from 1960 to 2010.

\begin{tabular}{|l|l|l|l|l|}
\hline Year & Completion SWL & Completion Yield & SWL in 2010 & Yield in 2010 \\
\hline 1960 & 11.2 & 12.8 & +1.2 & 0.7 \\
\hline 1970 & 10.1 & 8.6 & +1.0 & 1.3 \\
\hline 1980 & 6.7 & 4.9 & +0.8 & 1.1 \\
\hline 1990 & 4.7 & 4.8 & +0.6 & 1.1 \\
\hline 2000 & 1.8 & 2.8 & +0.5 & 0.6 \\
\hline 2010 & 0.1 & 1.4 & -0.5 & 0.4 \\
\hline
\end{tabular}

The average static water levels of 1960s, 1970s and 1980s boreholes were determined to be 11.2, 10.1 and $6.7 \mathrm{~m}$ above ground level (agl) at their times of completion while the 1990s, 2000s and 2010s boreholes had piezometric heads $4.7,1.8$ and $0.1 \mathrm{~m}$ agl at their completion times.

In evaluating the rates of decline both completion static water level and 2010 static water level of $1960 \mathrm{~s}-2010$ s boreholes and their present head are considered.

The piezometric head was gradually decreasing from $11.20 \mathrm{~m}$ agl in $1960 \mathrm{~s}$ to $0.1 \mathrm{~m}$ agl in 2010. The high piezometric head decline in1960s - 1970s was from $11.2 \mathrm{~m}$ agl to $10.1 \mathrm{~m}$ agl, yielding a decline of $1.1 \mathrm{~m}$. From $1970 \mathrm{~s}-1980 \mathrm{~s}$ the head dropped from 10.1 to $6.7 \mathrm{~m}$ agl, yielding a decline of $3.4 \mathrm{~m}$ agl. Furthermore, from 1980s to 1990s the decline was $5.4 \mathrm{~m}$ agl; from $10.1 \mathrm{~m}$ agl to $9.7 \mathrm{~m}$ agl whereas from $1990 \mathrm{~s}-2000 \mathrm{~s}$ it was $2.9 \mathrm{~m}$ agl, from $4.7 \mathrm{~m}$ agl to $1.8 \mathrm{~m}$ agl, and in 2010 the decline was $1.3 \mathrm{~m}$ agl from $1.8 \mathrm{~m}$ agl to $-0.5 \mathrm{~m}$ agl. There is gradual decline in the piezometric head and rates from 1990 to 2000, the declined and rate of decline are from $1.3 \mathrm{~m}$ to $0.13 \mathrm{~m} /$ year respectively. Population increase in the region and the conversion of many artesian wells to cement wells are believed to be responsible for these change. Furthermore the intervention by the local and state government in drilling boreholes for rural water supply is also a contributing factor. The decline is $1.7 \mathrm{~m}$ while the rate is $0.2 \mathrm{~m} /$ year, for 2000 to 2010 boreholes, this is because there is less borehole drilling programme due to high cost of drilling. The head of 1960, 1970 and 1980 boreholes in 2010 are $+1.2,+1.0$ and $+0.8 \mathrm{~m}$ agl respectively, while the heads of 1990,2000 and 2010 boreholes are $+0.6,+0.5$ and -0.5 respectively. It is calculated that the pressure head decline in the Middle zone aquifer is at the rate of $0.2 \mathrm{~m} /$ year for the past half a century based on piezometric heads of boreholes drilled from 1960 to 2010 tapping the Middle zone aquifer.

That their yields are also decreasing gradually from 1960 (12.8 1/s) to $2010(1.4 \mathrm{l} / \mathrm{s})$ is explained by the increase in the rate of exploitation, borehole construction method, borehole age among other factors. The boreholes locations used for the analysis of the decline in the piezometric head in the area over half a century is shown in fig.1.

The decline in the Pressure head of the Middle zone aquifer boreholes is caused principally by three (3) parameters. These are: The Percentage Screen, Yield and development period of boreholes.

In the 1960's boreholes, percentage screening does not follow the trend of 50-70\% screening increases the yield of borehole. It is obvious that screening boreholes up to 50-70\%; increases yield than does screened < 
$50-70 \%$. In this case some boreholes have high yield corresponding to the $\%$ screen while others have the reverse showing the haphazard methods of screening of boreholes in the Nigerian sectors of the Chad Basin, hence, showing scatter points without definite trend/relationship between the yield against the percentage screened of boreholes in 1960's (fig.3.).

The piezometric head of the Middle zone aquifer boreholes has declined over the past 30 years. The main reason for the declined has been the over abstraction and lack of replenishment. However factors such as the deterioration of the boreholes, boreholes interference and differences in borehole construction methods may also contribute to the observed declined.

The differences in the borehole construction methods, percentage of aquifer thickness screened and development hour's results in differences in the yield of boreholes drilled to the same depth, place and time. The three parameters of percentage screened, well diameter, and development hours have been analysed for boreholes from $1960-2010$.

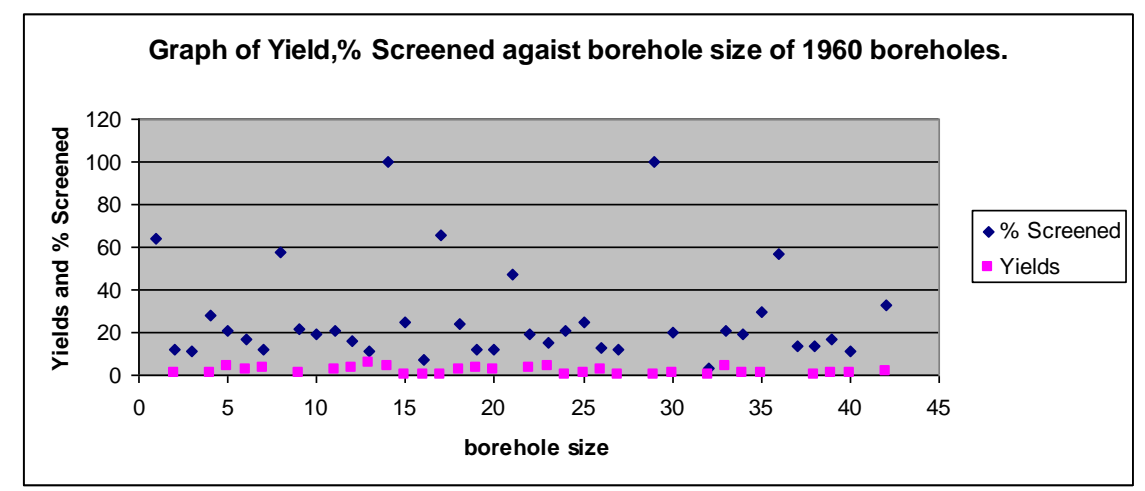

Fig. 3: Indicates the relationships between Percentage Screened and Yields against Borehole Size of 1960's boreholes. The plots does not show any cluster/ relationships hence show scattering of points.

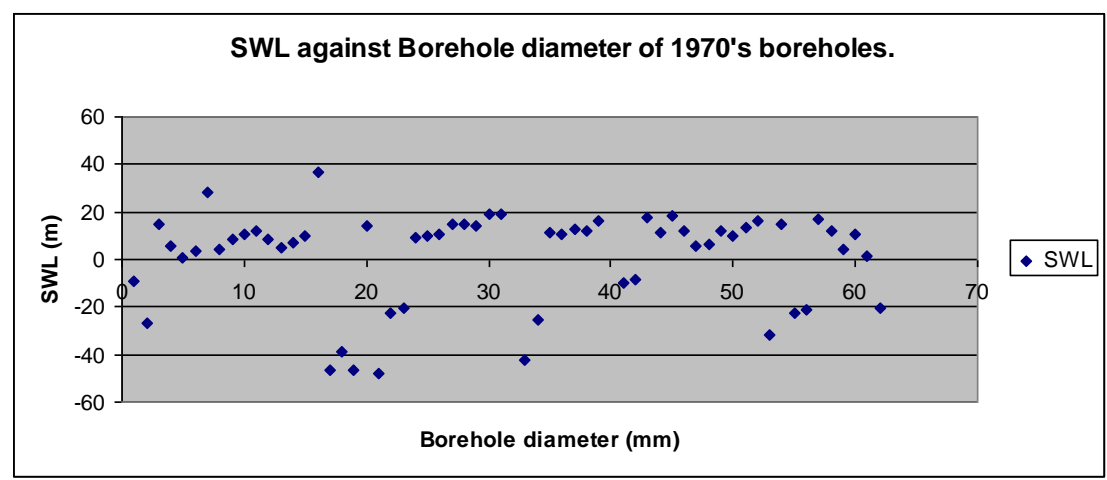

Fig.4: Graph of well diameter against static water level of 1970's boreholes. They are independent parameters that are not proportional to each other. The result shows no particular trend depicting scattering.

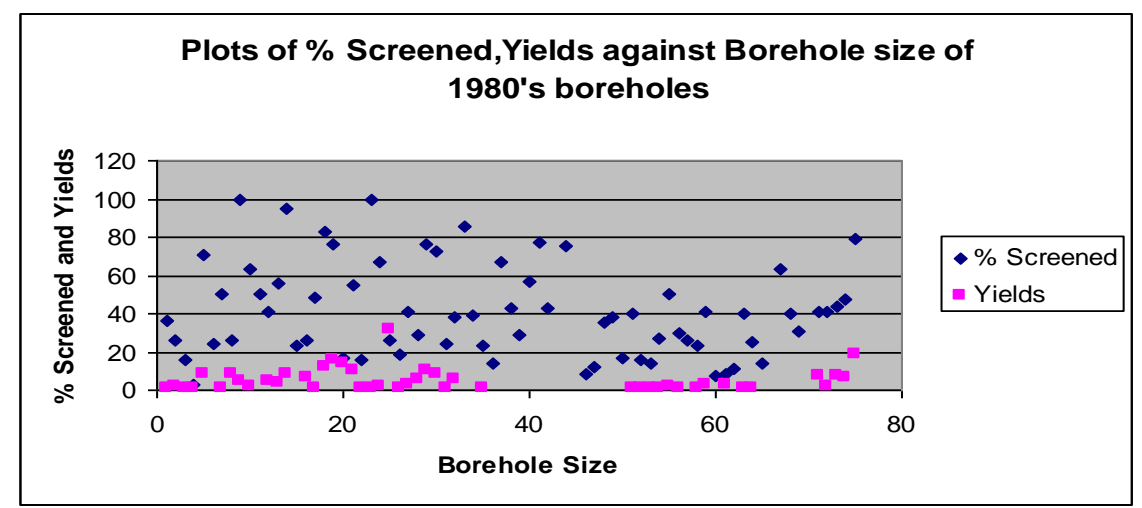

Fig.5: Is a plot of Percentage Screened and Yields against Borehole Size of 1980's boreholes. The three parameters are independent from each other. The result shows complete scattering of points indicating no relationships between the plotted parameters. 


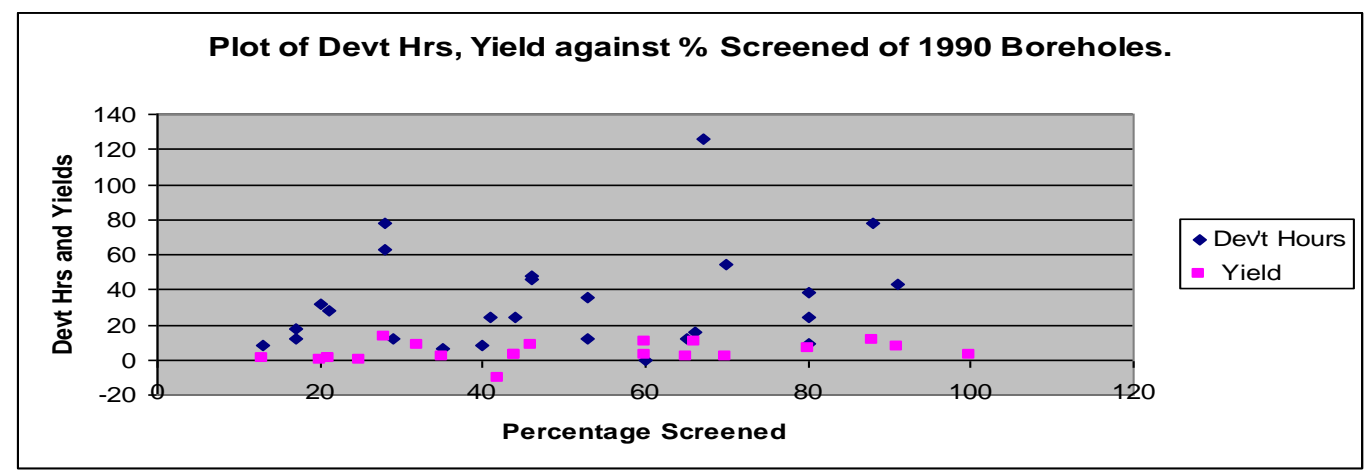

Fig.6: Shows the plots relationship of Development Hours and Yields against Percentage Screened of 1990's boreholes. The development hours and percentage screened does not control the yield of a borehole but rather it is controlled geologically (porosity, permeability, availability of water in the aquifer etc). The three parameters show no relationship hence showing scattering of points.

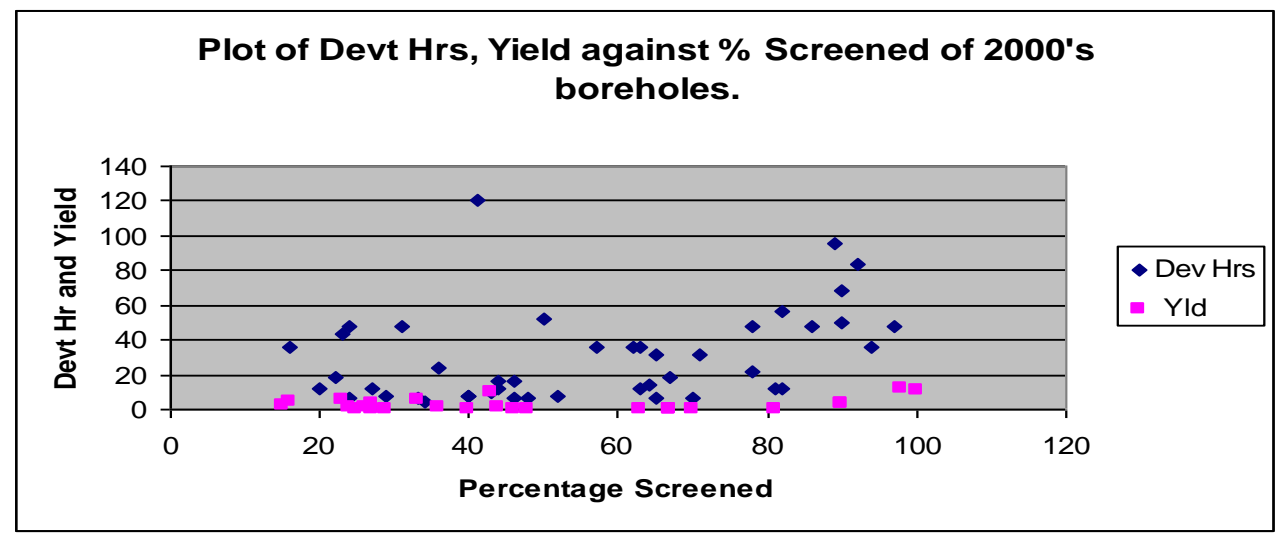

Fig.7: Is a plot of Percentage Screened of 2000's borehole against their yield and development hours. The geology of an area determines the yield of an aquifer and not external induced factors like percentage screened and development hours. The result shows no definite trend hence the three entities are independent from each other.

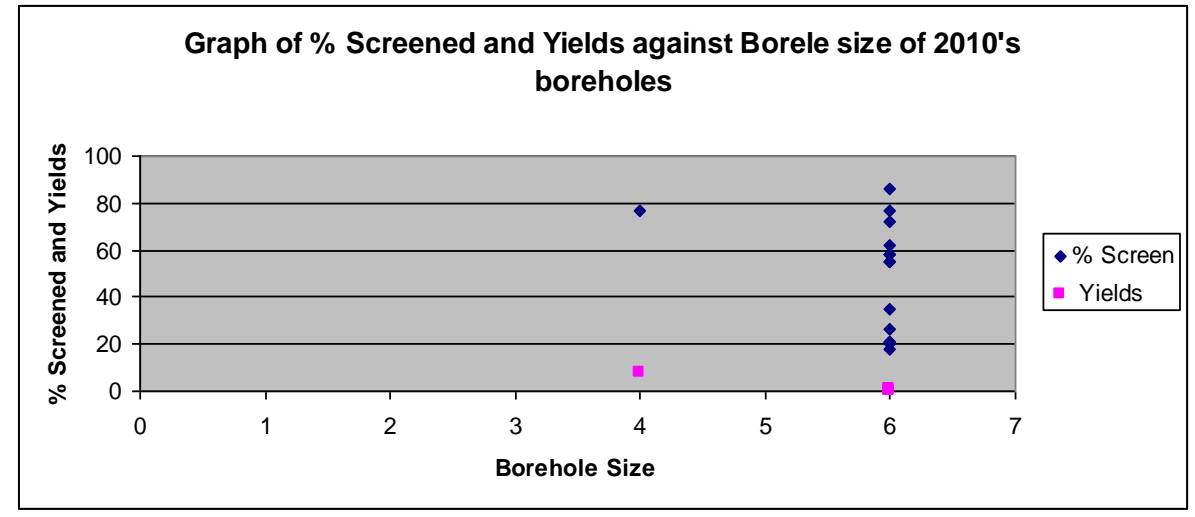

Fig.8: Depicts the relationship of Percentage Screened, Yields and Borehole size of 2010's boreholes. Yield is geologically controlled and not by borehole construction method. The plot does not show any particular trend hence depicts scattering of points.

The pressure heads are falling drastically due to indiscriminate and uncontrolled exploitation of the aquifer. There is still a noticeable decline in pressure surface of the free- flowing artesian wells in the Nigerian sector of the Chad Basin and consequently a shift in the limit of artesian flow in the pressure water of the Middle zone aquifer of the Chad Basin area eastward towards the lake with about $23 \mathrm{~km}$ for the last half a century (fig.2).

The water demand has dramatically increased over the last few decades, due to population growth and changes in life style. Not only has the demand increased due to the population growth, but there has also been a change in the life style of the people occasioned by modernization. This brought about a sharp increase in 
groundwater exploitation resulting in the decline of the piezometic head of the Middle zone aquifer (Oteze and Fayose, 1988).

\section{Conclusion}

The pressure head in the Middle zone aquifer is declining at the rate of $0.2 \mathrm{~m} /$ year for the past half a century. Their yields are also decreasing gradually from $1960(12.8 \mathrm{l} / \mathrm{s})$ to $2010(1.4 \mathrm{l} / \mathrm{s})$. This is explained by the increase in the rate of exploitation, borehole construction method, borehole age among other factors. Furthermore, lack of present day recharge to the Middle zone aquifer, heterogeneity and variable thickness of clay layer confining the zone play important role in the piezometic head declines of the Middle zone aquifer.

\section{Acknowledgement}

We thank the University of Maiduguri for providing the research grant and also the management of Alkal Consultant, Borno State Water Board, Chad Basin Development Authority and Conrad Nigeria limited for providing the required data for the paper.

\section{Referrences}

[1]. Adefila, S.F. (1975): Decline in the Pressure of the Middle Aquifer of the Chad Formation in Parts of the South Eastern Niger and North Eastern Nigeria. J. Mining and Geology, 12: 23-26.

[2]. Barber, (1965) W. and Jones, D.G. (1960): The Geology and Hydrology of Maiduguri, Bornu Province (Unpublished Records) Geological survey of Nigeria.

[3]. BRGM Consulting Company (1993): Monitoring and Management of Groundwater Resources in the Lake Chad Basin.Study Report for Lake Chad Basin Commission.47p

[4]. Carter, J.D., Barber, W., Tait, E.A., Jones, D.G. (1963): The Geology of Parts of Adamawa, Bauchi and Borno Provinces, Northeatern Nigeria: Bulletin of Geological Survey of Nigeria, No.30.

[5]. Dar Al-Handasah. (1983): Maidugrui Water Supply; Feasibility Study Final Report. Dar Al-Handasah ～(Shair and Partners):Maiduguri.

[6]. Goni, I.B.,M. Kachalla and M.M.Aji (2000):Another look at the Piezometic Head Declines in Middle Zone Aquifer of the Chad Formation in the South Western Chad Basin.Borno Jour. of Geology.Vol.2.No.2: 51-64.

[7]. Miller, R.E., Johnson, R.H., Olowu J.A.I. and Uzeoma J.U., (1968): Groundwater Hydrology of the Chad Basin in Borno and Dikwa Emirates; North-Eastern Nieria with Special Emphases on the Flows Life of the Artesian System. Hydrology of Africa and the Mediterranean Regions. USGS Water Supply Report, 1. 1757p.

[8]. Ndubisi, O.L., (1990): Managing GroundwaterbResources of the Lake Chad Basin in Nigeria. Proc.Nat.Hydrol.Symp.Maiduguri.Pp 429 - 436.

[9]. Offodile, M.E. (1972): Groundwater Level Fluctuation in the East Chad Basin of Nigeria. Min. Geol. Vol. 7. No. 1\&2: 19-34

[10]. Olugboye, M.O., (1995): Groundwater Monitoring Network as an aid to averting some Ecological Disaster, the Case for Chad Basin Area. Water Resources, Vol. 6 No.1\&2: 57-60.

[11]. Oteze, G.E. and Fayose, S.A. (1988): Regional Development in the Hydrogeology of Raeburn, C. and Jones, B., (1934): The Chad Basin Geology and Water Supply Bulletin of Geological Survey of Nigeria.No.15. 62p.

Appendix 2: Boreholes Parameters of 1960's Boreholes.

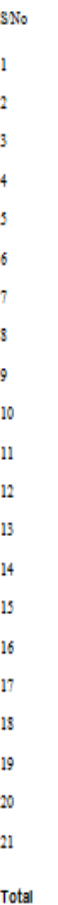

\begin{tabular}{|c|c|c|}
\hline$\infty$ & LGA & Lat \\
\hline Venen'y & Hearsere & $122^{8}+1.153$ \\
\hline & 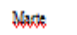 & 1215.09 \\
\hline 2529. & Gafa & 1314.781 \\
\hline Fement & 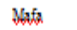 & 1310.206 \\
\hline Hexach & Nafor & 13200057 \\
\hline . & Whan & 1320.694 \\
\hline Novition & 称 & 1348262 \\
\hline FW & $\mathrm{Nogh}$ & 1408.642 \\
\hline 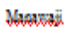 & $\mathrm{Noth}$ & 14083364 \\
\hline Gyonos & forthe & 1252329 \\
\hline Andinging & Gubing & 12158286 \\
\hline 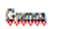 & Whot & 1342.629 \\
\hline Manki & Wother & 1216.594 \\
\hline ฟ⿻丷木 & Whasend & 1324.067 \\
\hline 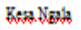 & Masment & 1208362 \\
\hline Gosetes & z & 1322261 \\
\hline Bzofem & 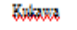 & 1316334 \\
\hline 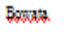 & Wother & 41.671 \\
\hline Pah & fowhos & 1247.891 \\
\hline Cingers. & sombing & 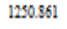 \\
\hline Bynm & fouph & 33.6 \\
\hline
\end{tabular}

\begin{tabular}{|c|c|}
\hline ong & $F_{t h}(m)$ \\
\hline 199364012 & 297 \\
\hline 130800 & $m$ \\
\hline 1002892 & 296 \\
\hline 1210284 & 298 \\
\hline 1200001 & 296 \\
\hline $115 s 542$ & 299 \\
\hline 12078964 & 291 \\
\hline 1215.499 & 286 \\
\hline 1226.867 & $m$ \\
\hline 1230.126 & 298 \\
\hline 1228994 & 308 \\
\hline 1212457 & 290 \\
\hline 1256.454 & 298 \\
\hline 1212052 & 291 \\
\hline 1320.057 & 299 \\
\hline 1325.492 & 250 \\
\hline $1312 s s 1$ & 283 \\
\hline 1307924 & 298 \\
\hline 1252416 & 296 \\
\hline 1238.684 & 294 \\
\hline 1238.991 & 299 \\
\hline
\end{tabular}

\begin{tabular}{|c|c|c|c|c|c|c|c|}
\hline Pop & $\mathrm{Crt}$ & $\mathrm{qH}$ & $I \times 6$ & $\mathrm{EC}$ & 栗 & $T D C$ & $A_{0} F_{06}$ \\
\hline 500 & 320 & 732 & 383 & 394 & 0.4 & 374 & \\
\hline 1000 & 1200 & 7.85 & 40.5 & 680 & 0.5 & 310 & \\
\hline 390 & 2600 & 72 & 37.7 & 1224 & 0.4 & 299 & \\
\hline 300 & 800 & 72 & 37.6 & 960 & Premp & 308 & \\
\hline 510 & 7000 & 69 & 39.1 & 820 & 0.8 & 313 & 0 \\
\hline 2500 & . & 7.1 & 38.2 & 1126 & 2 & 283 & \\
\hline 320 & 1000 & 6.86 & 36.4 & 1026 & 0.2 & 268 & \\
\hline 260 & 700 & 7.82 & 368 & 908 & 0.3 & 290 & \\
\hline 820 & 2500 & 7.6 & 37.4 & 840 & 0.4 & 315 & \\
\hline 1500 & 2000 & 7.4 & 38.2 & 472 & 6 & 325 & \\
\hline 320 & . & 72 & 36.8 & 408 & 2 & 333 & \\
\hline 1200 & 10,000 & 7.1 & 373 & 1005 & 0.4 & 250 & \\
\hline 250 & 990 & 7.05 & 38.2 & 366 & 0.5 & 312 & \\
\hline 250 & 2000 & 6.8 & 40 & 852 & 12 & 393 & \\
\hline 560 & 20,000 & 6.8 & 38.6 & 846 & 2 & 352 & \\
\hline 400 & 1200 & 654 & 36.8 & 1170 & 0.6 & 344 & \\
\hline 560 & 3000 & 6.4 & 36.8 & 1050 & 0.8 & 369 & \\
\hline 740 & 1400 & 7.12 & 36.6 & 940 & 2 & 332 & \\
\hline 190 & 250 & 72 & 36.4 & 870 & 0.3 & 312 & \\
\hline 420 & 2500 & 73 & 37.7 & 485 & 0.4 & 361 & \\
\hline 460 & 1200 & 7.4 & 35.5 & 842 & 0.4 & 318 & \\
\hline
\end{tabular}

\begin{tabular}{|c|c|c|}
\hline$\sum_{p o r}$ & $\%$ & Dev Hr \\
\hline $\begin{array}{l}349 \\
370\end{array}$ & 54 & \\
\hline $\begin{array}{l}276 \\
304\end{array}$ & 15 & 108 \\
\hline $\begin{array}{l}225 . \\
290\end{array}$ & 82 & 98 \\
\hline $\begin{array}{l}251 \\
277\end{array}$ & 89 & 83 \\
\hline $\begin{array}{l}279 . \\
299\end{array}$ & 89 & 56 \\
\hline $\begin{array}{l}258 \\
274\end{array}$ & 22 & \\
\hline $\begin{array}{l}255 \\
259\end{array}$ & 60 & \\
\hline $\begin{array}{l}274 . \\
2800\end{array}$ & 21 & \\
\hline $\begin{array}{l}2099- \\
2956\end{array}$ & 24 & \\
\hline $\begin{array}{l}317 . \\
323\end{array}$ & 33 & \\
\hline $\begin{array}{l}318- \\
324\end{array}$ & 13 & \\
\hline 274 & 22 & \\
\hline $\begin{array}{l}297 \\
303\end{array}$ & 30 & \\
\hline $\begin{array}{l}314 \\
344\end{array}$ & $\pi 7$ & 94 \\
\hline $\begin{array}{l}311 \\
341\end{array}$ & 75 & 88 \\
\hline $\begin{array}{l}325- \\
332\end{array}$ & 23 & 72 \\
\hline $\begin{array}{l}350 \\
3550\end{array}$ & 18 & \\
\hline $\begin{array}{l}281 . \\
287\end{array}$ & & \\
\hline 292 & 29 & \\
\hline $\begin{array}{l}298 \\
3.55\end{array}$ & 22 & \\
\hline 351 & 11 & \\
\hline 293 & 20 & \\
\hline
\end{tabular}

\begin{tabular}{|c|c|c|c|c|}
\hline$\frac{C_{p l}}{s W L}$ & $2 \times 4$ & 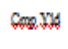 & Sertst & $\mathrm{Aq} \cdot \mathrm{nI}$ \\
\hline 6.9 & & 12.4 & 21 & 39 \\
\hline 10.8 & & N.D & 28 & 199 \\
\hline 13.6 & & 1.3 & 45 & 55 \\
\hline 15.2 & & 1.5 & 16 & 18 \\
\hline 10 & & 12 & 20 & 36 \\
\hline N.D & & 0.01 & 6 & 27 \\
\hline 142 & & 1.3 & 3 & 5 \\
\hline 14.6 & & 1.7 & 6 & 28 \\
\hline 15.8 & & & 7 & 29 \\
\hline 6.1 & & 1.3 & 6 & 18 \\
\hline-0.9 & 22 & & 6 & 47 \\
\hline 13.9 & & 1.3 & 3 & 14 \\
\hline 62 & & 1 & 6 & 20 \\
\hline 12.12 & & 35.4 & 30 & 39 \\
\hline 12.12 & & 34.7 & 30 & 40 \\
\hline 20 & & 4 & 6 & 26 \\
\hline 20.3 & & 4 & 6 & 34 \\
\hline 3.9 & & 0.2 & 6 & 21 \\
\hline 7.4 & & 25 & 6 & 27 \\
\hline 82 & & 3.3 & 6 & di \\
\hline 46 & & 1 & 6 & 31 \\
\hline
\end{tabular}

107.3 


\begin{tabular}{|c|c|c|c|c|c|c|c|c|c|c|c|c|c|c|c|c|c|c|c|c|c|c|c|}
\hline & & & & & & & & & & & & ers. & & & & & & & & & & & \\
\hline SNo & tox & LGA & Lst & Losig & $\operatorname{Ex}(m)$ & 2010 & $\mathrm{Ppp}$ & cat & 粗 & In & EC & W & Yas & $\mathbb{T D C}$ & 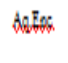 & seppos & $\begin{array}{l}\% \\
\&\end{array}$ & DevH & क & 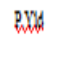 & 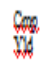 & Sorts & \\
\hline 1 & Framl & Nasmoni & 1215.78 & 1247.946 & 311 & .246 & 300 & 900 & 76 & 325 & 994 & met! & 1976 & 340 & $\frac{233}{323}$ & $283 \cdot 331$ & 68 & $\eta 1$ & 905 & 8.5 & & 40 & 48 \\
\hline 2 & satos & Band & 1238.8 & 1141.667 & 332 & .47 .6 & 300 & 100 & 7.6 & 338 & 399 & 1 & 1976 & 246 & 0.232 & $127 \cdot 230$ & 9 & $n$ & .2688 & 13.7 & & 16 & 32 \\
\hline 3 & 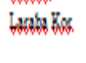 & Fom & 1200.63 & 1337.032 & 298 & $\mathrm{NA}$ & 800 & . & $6 s$ & 343 & $M$ & m:!I & 197 & 3.4 & $\begin{array}{l}320 . \\
346\end{array}$ & $321 \cdot 343$ & 8 & . & 19.16 & & 227 & $n$ & 6 \\
\hline 4 & 跳 & Gowe & 12438 & 1230862 & 293 & $\mathrm{NA}$ & 200 & 400 & 72 & 392 & 99 & 3 & 197 & 328 & $\begin{array}{l}300 \cdot \\
328\end{array}$ & $306 \cdot 315$ & 36 & & 38 & & 0.6 & 9 & 28 \\
\hline 1 & BNow & Nothy & 1.24 .29 & 1213.694 & 300 & $\mathrm{NA}$ & 340 & 900 & 132 & 37.6 & 362 & 2 & 197 & 298 & $\begin{array}{l}274 \cdot \\
298\end{array}$ & $299 \cdot 299$ & $x$ & & 0.6 & & 0.1 & 6 & 24 \\
\hline 6 & 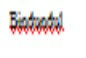 & Grone & 13254 ? & $1246.29 !$ & 298 & $\cdot 124$ & 420 & 800 & 72 & 286 & 960 & met! & 1977 & 319 & $\begin{array}{l}298 \\
307\end{array}$ & $300 \cdot 306$ & 40 & & 36 & & 09 & 6 & 15 \\
\hline$?$ & 7 ingle & follog & 1328.63 & 1248.123 & 299 & .128 & 330 & $\cdot$ & $\cdot$ & . & $\cdot$ & me!l & 197 & 326 & $\frac{298 .}{326}$ & $318 \cdot 324$ & 21 & & 28 & & 12 & 6 & 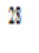 \\
\hline 8 & tai & Guins & 13399 & 124.21 & 297 & .21 .6 & 1200 & 3000 & 18 & 34.8 & 860 & 6 & 197 & 321 & $\begin{array}{l}300 \cdot \\
321\end{array}$ & $303 \cdot 306$ & 19 & & 39 & & 0.1 & 3 & 21 \\
\hline 9 & $7 \mathrm{x}$ & Nobly & 1448.76 & 1312289 & 319 & 13 & 420 & 1.50 & 6,06 & 426 & 1392 & 1 & 1977 & 333 & $\begin{array}{l}286 \cdot \\
323\end{array}$ & $288 \cdot 318$ & 81 & 1111 & 839 & & 368 & 30 & 37 \\
\hline 10 & Domporat & Nothe & 131216 & 1288086 & 293 & 123 & 120 & 160 & 6.46 & 39.8 & 862 & 0.8 & 197 & 318 & $\begin{array}{l}296 . \\
318\end{array}$ & $29 \cdot 316$ & 96 & 76 & 1091 & & 6.1 & 19 & M \\
\hline 11 & 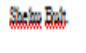 & Nohkhe & 1320.49 & 1296068 & 298 & 0.6 & 100 & 150 & 63 & $38 ?$ & 97 & 0.6 & 1977 & 326 & $\begin{array}{l}304 \cdot \\
326\end{array}$ & $304 \cdot 310$ & 27 & & 11.8 & & 13 & 6 & 22 \\
\hline 12 & Gumas & Nother & 132217 & $1: 247.006$ & 300 & 1 & 3200 & 6000 & 633 & 40 & 34 & 2 & 197 & 381 & $\begin{array}{l}299 . \\
318\end{array}$ & $298 \cdot 316$ & 99 & 8 & 85 & & Bs & 17 & 19 \\
\hline 13 & BNWWi & Nossem & 1218.73 & 1324.457 & 298 & 36 & 400 & 800 & 7.4 & 33.4 & 402 & 1.4 & 1977 & 366 & $\begin{array}{l}300 \cdot \\
331\end{array}$ & $327 \cdot 345$ & 39 & 34 & 1 & & 4 & 18 & n \\
\hline 14 & What & Now & 12002 & 1310.128 & 310 & 0.7 & 300 & 680 & 1.4 & 368 & 70 & 0.4 & 197 & 33 & $\frac{319 \cdot}{316}$ & $342 \cdot 373$ & 46 & 26 & $?$ & & 69 & 28 & 61 \\
\hline 15 & Fond & $7 \mathrm{x}$ & 132726 & 1286334 & 296 & 03 & 480 & 1000 & 68 & 342 & 602 & 03 & 1977 & 306 & $\frac{338 \cdot}{370}$ & $339 \cdot 369$ & 94 & 60 & 10.1 & & 13 & 30 & $\pi$ \\
\hline 16 & thets & Hasmeni & 1211.67 & 1219.512 & 342 & 263 & 600 & 1280 & 62 & 38.6 & 394 & n:I & 1977 & $23 !$ & $\begin{array}{l}219 \cdot \\
231\end{array}$ & $218 \cdot 27$ & 78 & $\eta 2$ & 364 & & $?$ & 9 & 12 \\
\hline 17 & DAGDTR & Dremes & 1.14433 & 11197.967 & 362 & .338 & 1000 & & 7.4 & 339 & 300 & 2 & 197 & 200 & $90 \cdot 131$ & $85 \cdot 147$ & 60 & 162 & .46 .7 & 122 & & 37 & . \\
\hline 18 & DA9DIR & Dhemest & 1.4732 & 1138211 & 363 & .362 & 700 & . & 13 & 386 & 410 & 2 & 197 & 303 & $\begin{array}{l}139 \cdot \\
200\end{array}$ & $186 \cdot 202$ & 27 & $\theta$ & 386 & 2 & & $n$ & 19 \\
\hline \multicolumn{5}{|c|}{ Arerage } & .26 & & & & & & $\begin{array}{l}1.25 \\
125\end{array}$ & & & & & & & 1 & & 8.6 & & & \\
\hline
\end{tabular}

\section{Appendix 3: 1970s Boreholes}

\begin{tabular}{|c|c|c|c|c|c|c|c|c|c|c|c|c|c|c|c|c|c|c|c|c|c|c|c|}
\hline & & & & & & & & & & & Pars & neters. & & & & & & & & & & & \\
\hline 31. & Los & LGA & Lst & Loag & $\mathbb{E}(x)(\mathrm{m})$ & \$N/10 & $\mathrm{Pop}$ & $\mathrm{ct}$ & $\mathrm{PH}$ & $N C$ & $\mathrm{EC}$ & $\begin{array}{l}W \\
\mathrm{is}\end{array}$ & Yess & $T D C$ & 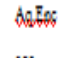 & $\mathrm{Sor}_{\mathrm{O}}$ & $\begin{array}{l}\% \\
\&\end{array}$ & Dev Hs & ad & 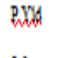 & $\mathrm{cm}$ & Scrta & $\mathrm{Ag}$ th \\
\hline & 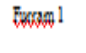 & Hasmen & 1215.78 & 1247946 & 311 & 24.6 & 300 & 900 & 7.6 & 325 & 894 & netl & 1976 & 340 & $\frac{283 \cdot}{323}$ & $\begin{array}{l}283 \cdot \\
331\end{array}$ & 68 & 71 & 9.05 & 85 & & 40 & 48 \\
\hline & stogs & Fma & 123828 & 1141.667 & 332 & 47.6 & 300 & 100 & 7.6 & 33.8 & 395 & 1 & 1976 & 246 & 0.232 & $\begin{array}{l}127 \cdot \\
230\end{array}$ & 9 & $n 2$ & 2688 & 13.7 & & 16 & 232 \\
\hline & Hatem $7 \%$ & 개에 & 120.63 & 1337.032 & 298 & $\mathrm{NA}$ & 900 & $\cdot$ & 63 & 343 & $M$ & "ะแ & 197 & 3.4 & $\begin{array}{l}320 \cdot- \\
346\end{array}$ & $\begin{array}{l}321 \cdot \\
343\end{array}$ & 89 & . & 15.16 & & $22 ?$ & $n$ & 26 \\
\hline & $\mathrm{B}_{\mathrm{N}} \mathrm{x}$ & Sybin & 1243.8 & 1230862 & 293 & $\mathrm{NA}$ & 20 & 400 & 72 & 39.2 & 992 & 1 & 197 & 328 & $300 \cdot$ & $\begin{array}{l}306 \cdot \\
315\end{array}$ & 36 & & 38 & & 0.6 & 9 & 25 \\
\hline & Z X w & Nothy & 12.24 .29 & 1215.694 & 300 & $\mathrm{NA}$ & 340 & $\$ 00$ & 732 & 37.6 & 362 & 2 & 197 & 298 & $\begin{array}{l}274 \cdot \\
298\end{array}$ & $\begin{array}{l}299 . \\
298\end{array}$ & 25 & & 0.6 & & 0.1 & 6 & 24 \\
\hline & Bindedx & quan & 1328.47 & 1246.291 & 298 & 1.24 & 420 & 900 & 72 & 28.6 & 960 & สะ⿺𠃊 & 1977 & 319 & $\begin{array}{l}292 \cdot \\
307\end{array}$ & $\begin{array}{l}300 \cdot \\
306\end{array}$ & 40 & & 3.6 & & 09 & 6 & 15 \\
\hline & 7 zimole & Gove & 1325.63 & 1248.123 & 299 & 128 & 330 & $\cdot$ & . & . & $\cdot$ & พเII & 1977 & 326 & $\frac{298 \cdot}{326}$ & $\begin{array}{l}318 \cdot \\
324\end{array}$ & 21 & & 28 & & 12 & 6 & 28 \\
\hline & tมi & Govis & 132593 & 1244.21 & 297 & $i_{216}$ & 1200 & 3000 & 78 & 34.8 & 860 & 6 & 197 & 321 & $\frac{300 \cdot}{321}$ & $\begin{array}{l}303 . \\
306\end{array}$ & 15 & & 39 & & 0.1 & 3 & 21 \\
\hline & $7 \mathrm{si}$ & Nobhy & 1148.76 & 1312287 & 319 & 13 & 420 & 1500 & 6,06 & 426 & 1302 & 1 & 197 & 323 & $336 \cdot$ & $\begin{array}{l}288 \\
318\end{array}$ & 81 & 111 & 839 & & 368 & 30 & 37 \\
\hline & Thember: & Nothy & 131216 & 1288086 & 293 & 1.23 & 120 & 160 & 6.46 & 39.8 & 862 & OS & 197 & 318 & $\begin{array}{l}196 \cdot \\
318\end{array}$ & $\begin{array}{l}297 \\
316\end{array}$ & 96 & 76 & 1091 & & 6.1 & 19 & $n$ \\
\hline & 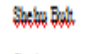 & Nothy & 1320.49 & 1286068 & 298 & 0.6 & 100 & 180 & 63 & 38.7 & $9 n$ & 0.6 & 1977 & 326 & $\begin{array}{l}304 \cdot \\
326\end{array}$ & $\begin{array}{l}304 . \\
310\end{array}$ & 27 & & 11.8 & & 13 & 6 & $n$ \\
\hline & Gugars & Nobhy & 1322.17 & $12: 247.306$ & 300 & 1 & 3200 & 6000 & 633 & 40 & 844 & 2 & 1977 & 391 & $\frac{199}{318}$ & $\begin{array}{l}298 \\
316\end{array}$ & 9 & 8 & $B S$ & & 15 & 17 & 19 \\
\hline & Bdybi & Nonsem & 1218.73 & 1324.467 & 298 & 3.6 & 480 & 900 & 7.4 & 33.4 & 452 & 1.4 & 1977 & 366 & $\begin{array}{l}300 \cdot \\
3.1\end{array}$ & $\begin{array}{l}327 \cdot \\
345\end{array}$ & 38 & 34 & 1 & & 4 & 18 & $\$ 1$ \\
\hline & Jalos. & Nomp & 120028 & 1310.128 & 310 & 0.7 & 300 & 680 & 7.4 & 368 & 720 & 0.4 & 1977 & 393 & $\begin{array}{l}315 . \\
376\end{array}$ & $\begin{array}{l}342 . \\
372\end{array}$ & 46 & 26 & 7 & & 65 & 28 & 61 \\
\hline & Fow $\mathrm{L}$ & BW & 132726 & 1256334 & 296 & OS & 480 & 1000 & 68 & 342 & 652 & 03 & 1977 & 396 & 3380 & $\begin{array}{l}339 \cdot \\
369\end{array}$ & 94 & 60 & 10.1 & & 39 & 30 & 32 \\
\hline & Whiln & Nasmen & 1211.67 & $1219 s 12$ & 342 & 263 & 600 & 1280 & 62 & 39.6 & 394 & me!l & 197 & 231 & $\begin{array}{l}219 \cdot \\
231\end{array}$ & $\frac{218}{217}$ & 78 & $n$ & 36.4 & & 7 & 9 & 12 \\
\hline & DA6DTR & Drences. & 1144.33 & 1157.96? & 362 & 338 & 1000 & ${ }^{\circ}$ & 7.4 & 39.5 & 390 & 2 & 1977 & 280 & $\begin{array}{l}90 . \\
131\end{array}$ & $\begin{array}{l}85 \cdot \\
147\end{array}$ & 60 & 162 & .46 .7 & 12.2 & & 37 & $6 ?$ \\
\hline & DA9DTR & Drencese & 114732 & 1198211 & 363 & 362 & 700 & . & 73 & 38.6 & 410 & 2 & 1977 & 303 & $\begin{array}{l}139 \cdot \\
200\end{array}$ & $\begin{array}{l}156 . \\
202\end{array}$ & 27 & 99 & .386 & 2 & & 22 & 79 \\
\hline & & & & & .26 & & & & & & $\begin{array}{l}\frac{1.25}{125} \\
125\end{array}$ & & & & & & & 10.1 & & 8.6 & & & \\
\hline
\end{tabular}


Appendix 5: 1990 s Boreholes Data.

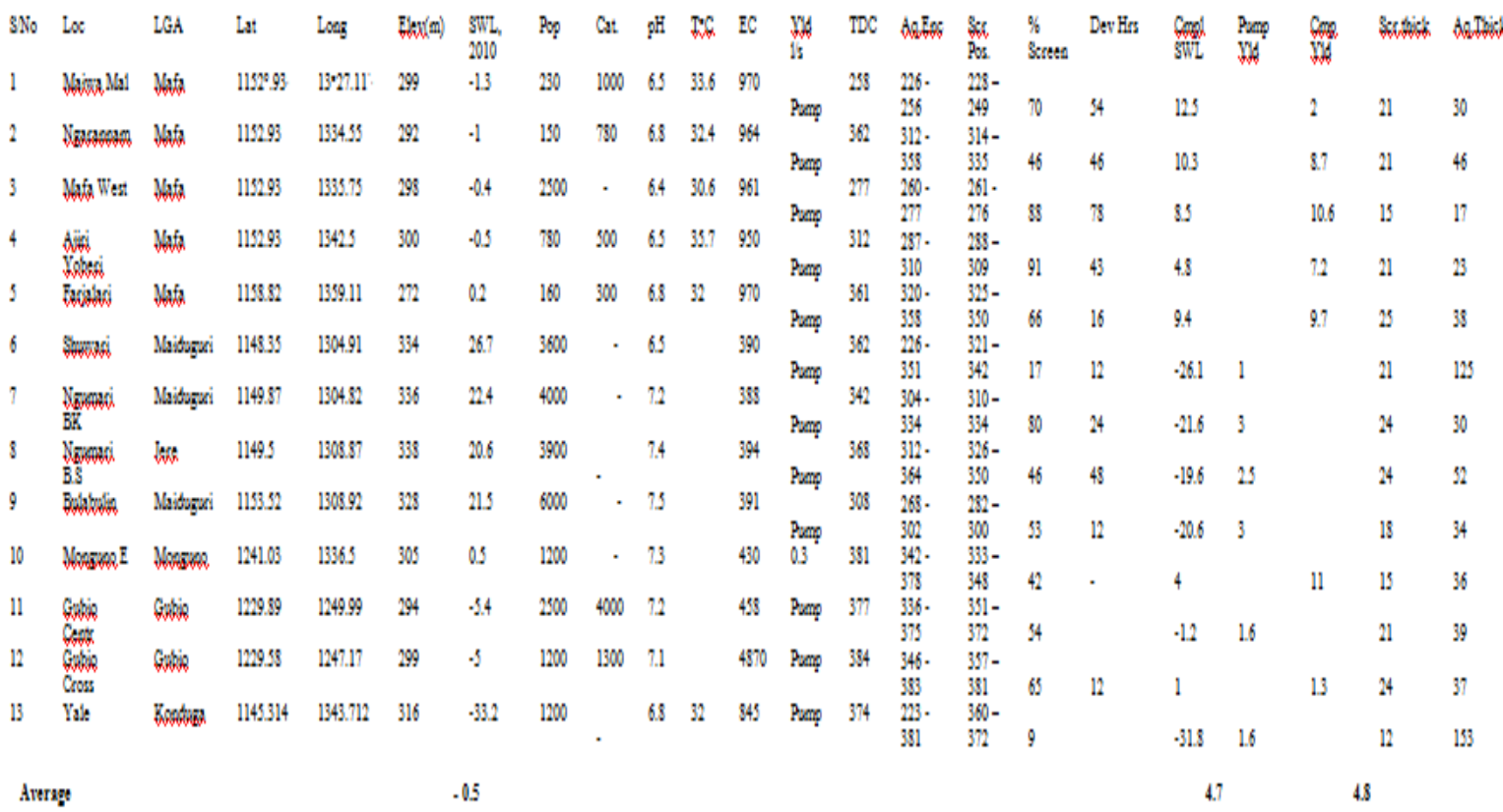

\begin{tabular}{|c|c|c|c|c|c|c|c|c|c|c|c|c|c|c|c|c|c|c|c|c|c|c|}
\hline SNo & Loc & LGA & Lat & Long & $\mathbb{E}(t)(m)$ & $5 x$ & Pep & $\mathrm{Cr}$ & $\mathrm{pH}$ & ING & EC & Wh & $\mathrm{TDC}$ & $\mathrm{AB}$ 파. & Serees & $\%$ & Dev Hs & $\mathrm{Cp}_{2}$ & p & cal & Serth & 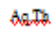 \\
\hline 1 & Gagadi & thas & $12 * 14.127$ & $13 \cdot 52.134$ & 260 & o. & 500 & - & 69 & 34 & 877 & well & 296 & $\begin{array}{l}273-- \\
292\end{array}$ & $275-287$ & 63 & 36 & 0.6 & & & 12 & 19 \\
\hline 2 & Bing & Jafo & 1148.46 & 1328.53 & 242 & 09 & 500 & 350 & 69 & 37 & 920 & 2 & 309 & $\begin{array}{l}2800- \\
291\end{array}$ & $278 \cdot 290$ & 81 & 12 & 0.6 & & as & 9 & 11 \\
\hline 3 & Mal Mag & $D \times$ & $1210.5 s$ & 135223 & 281 & 0.6 & 1100 & $\$ 40$ & 6.6 & 36 & 800 & 0.4 & 275 & $\frac{229-}{236}$ & $230-242$ & 44 & 12 & 0.8 & & 0.6 & 12 & 27 \\
\hline 4 & $\mathrm{BH}$ & Kala Bals: & 1226.66 & 134823 & 322 & -1.3 & 425 & 460 & 69 & 36 & 900 & - & 322 & $\begin{array}{l}246- \\
322\end{array}$ & $308-320$ & 16 & 36 & -13 & 2 & & 12 & 76 \\
\hline 3 & Gaxk & ) & 1136.79 & 1334.54 & 294 & 0.8 & 1220 & 900 & 69 & 33 & 920 & 0.6 & 240 & ${ }_{238}^{215}$ & $220 \cdot 235$ & 65 & 6 & -1.2 & 3 & & 15 & 23 \\
\hline 6 & $z_{\mathrm{s}} \mathrm{se}$ & sompo & 1286.94 & 1215.86 & 375 & 19 & 990 & $=$ & 73 & 40 & 850 & 13 & 375 & 330. & $362-374$ & 27 & 2 & 19 & & 0.3 & 12 & 45 \\
\hline$?$ & Wwand 3 & Maitugeni & 1147.11 & 1313.21 & 326 & -24.5 & $=$ & & 7.4 & 39 & 392 & - & 274 & 235. & $236-260$ & 62 & 36 & -21.6 & $\mathrm{NA}$ & & 24 & 39 \\
\hline 8 & CEN QAN & Maitugani & 1132.69 & 1307.44 & 338 & $\mathrm{NA}$ & - & & - & - & - & Dead & 248 & ${ }_{248}^{216-}$ & $220 \cdot 238$ & 56 &. & .228 & 62 & & 18 & 32 \\
\hline 9 & Doimgids.1 & Maibugai & 1144.34 & 131135 & 333 & .25 & 1000 & . & 6.8 & 33 & 396 & Pemp & 282 & 235. & $261 \cdot 282$ & 78 & 48 & -24.3 & 3.6 & & 21 & 27 \\
\hline 10 & $\mathrm{Nat} F \mathrm{fox}$ & Mastugeni & $12 \cdot 55.431$ & $13 \% 33.604$ & 267 & 12 & 200 & 100 & 83 & 39 & 468 & 0.2 & 459 & $413-$ & $454 \cdot 483$ & 43 & 10 & 1.1 & & 9.4 & 29 & 67 \\
\hline 11 & $\mathrm{Kin}=600 \mathrm{x}$ & smang & 1248.18 & 1321.15 & 312 & 0.6 & 590 & 250 & 7.1 & 39 & 785 & 0.6 & 375 & $319-$ & $346 \cdot 360$ & 33 & 6 & 1.3 & & 5 & 14 & 42 \\
\hline 12 & $\mathrm{Baresp}$ & Nobler & 1307.41 & 1313.32 & 352 & -1.2 & 1160 & - & 72 & 40 & 410 & - & 301 & $\begin{array}{l}234 \cdot- \\
301\end{array}$ & $284-298$ & 82 & 12 & -15 & & - & 14 & 17 \\
\hline 13 & Gasterex & $\mathrm{Nogh}$ & 1221.27 & 1408.81 & 248 & -28 & $=$ & - & 6.8 & 37 & 350 & - & 354 & $\frac{282}{336}-$ & $309-333$ & 44 & 16 & -12 & 25 & & 24 & 54 \\
\hline 14 & WomiLC & teras & 1159.45 & 1308.62 & 344 & $\mathrm{NA}$ & $=$ & 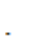 & 72 & 37 & 390 & Premp & 324 & $\frac{232-}{306}$ & $275 \cdot 305$ & 97 & 48 & -25.6 & 4.8 & & 30 & 31 \\
\hline 15 & Woth difind & thes & 1384.36 & 1305.66 & 321 & -222 & 1000 & 500 & 7.1 & 40 & 540 & Promp & 268 & ${ }_{238}^{231 \cdot}$ & $247 \cdot 268$ & 37 & 36 & -20.6 & 24 & & 21 & 37 \\
\hline 16 & Iक⿻𨈑口 & feras & 1157.46 & 1307.72 & 333 & -265 & $=$ & & 72 & 37 & 390 & Peamp & 258 & 224. & $244 \cdot 258$ & 41 & 120 & .252 & 8.4 & & 14 & 34 \\
\hline 17 & Hasmedi & ) & 1208.67 & 1243.37 & 345 & -28.2 & 1000 & 500 & 6.5 & 40 & 906 & Pramp & 333 & $\begin{array}{l}779- \\
316\end{array}$ & $285-309$ & 65 & 32 & -26.4 & 5.7 & & 24 & 37 \\
\hline 18 & SDWhor & $D \%$ & $12 \cdot 02.650$ & $13 \cdot 55.267$ & 287 & 0.8 & 950 & - & 7 & 36 & 810 & 0.5 & 270 & $\begin{array}{l}240- \\
270\end{array}$ & $256-268$ & 40 & 8 & 0.4 & & 0.3 & 24 & 30 \\
\hline 19 & As Traven & 杵的 & 120249 & 1303.36 & 292 & -12 & 280 & . & 69 & 31 & 668 & - & 299 & $\begin{array}{l}258 \text { - } \\
293\end{array}$ & $250-292$ & 34 & 4 & -4.2 & 2 & & 12 & 35 \\
\hline 20 & Toposite & Noun & 1400.58 & 1216.04 & 312 & 0.8 & 620 & 140 & 38 & 38 & 900 & 0.7 & 312 & $\begin{array}{l}246- \\
306\end{array}$ & $283 \cdot 298$ & 25 & & 0.8 & & 0.4 & 15 & 60 \\
\hline & gat & & & & -0 & & & & & & & & & & & & 18 & & 28 & & & \\
\hline
\end{tabular}


Appendix 7: 2010's Boreholes Parameters.

\begin{tabular}{|c|c|c|c|c|c|c|c|c|c|c|c|c|c|c|c|c|c|c|c|c|c|c|c|}
\hline SNo & $L x$ & LGA & Ls: & Losig & $\operatorname{Et}(m)$ & 2010 & 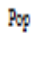 & at & pH & $I C$ & $\mathrm{EC}$ & $\begin{array}{l}\text { W } \\
\text { i: }\end{array}$ & Year & $T D C$ & $A_{0}{ }_{0}=0$. & Sorpor & $\begin{array}{l}\% \\
8:\end{array}$ & DevHr & ald & $2 W=$ & $\mathrm{Y}$ & s.t. & $\mathrm{A}_{0} \mathrm{Am}$ \\
\hline 1 & 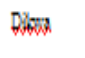 & $D \times$ & 120265 & 1398.77 & 288 & .18 & 850 & & 68 & 36.1 & $M$ & $\mathrm{rmog}$ & 2010 & 272 & $\begin{array}{l}24 ! \cdot \\
272\end{array}$ & $\begin{array}{l}246 . \\
200\end{array}$ & $n$ & 80 & -2 & 13 & & 24 & 31 \\
\hline 2 & Dyento & Nother & & & & & & & & & & & & & 420. & 429. & & & & & & & \\
\hline & & 7 & 1308.54 & 12340.02 & 334 & .62 & 1000 & & 7.4 & 333 & 428 & Prop & 2010 & 446 & $\begin{array}{l}46 \\
395 .\end{array}$ & $\begin{array}{l}444 \\
399 .\end{array}$ & 18 & 48 & .73 & 23 & & 15 & 26 \\
\hline & से & Dew & 1308.71 & 1349.2 & 267 & $\cdot 0.7$ & 1300 & & 73 & 333 & 418 & Prop & 2010 & 420 & 420 & 417 & $\eta$ & 10 & 0.5 & & 03 & 18 & 23 \\
\hline 4 & Gomber & Nom & 1221.27 & 140881 & 271 & .412 & 800 & - & 6.8 & 32 & 839 & Pras & 2010 & 388 & 321. & $332 \cdot$ & 88 & 8 & 0.4 & & 0.3 & 18 & 31 \\
\hline 6 & Bimm & Whow & 121622 & 1340.39 & 346 & 02 & 200 & & 7.4 & 34.1 & 764 & Pras & 2010 & 392 & $\begin{array}{l}34.4 \cdot \\
392\end{array}$ & $372 \cdot$ & 21 & · & 03 & & 0.2 & 6 & 28 \\
\hline 6 & Nasment & Nasment & 1207.41 & 124431 & 322 & .275 & 420 & 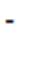 & 69 & 39.8 & 394 & Pras & 2010 & 298 & $262 \cdot$ & $\begin{array}{l}281 \cdot \\
293\end{array}$ & 35 & - & -24.5 & 2 & $\cdot$ & 12 & 34 \\
\hline 8 & ing & Ging & 1318.43 & 133648 & 294 & .03 & 1600 & & 68 & 37 & 971 & Pras & 2010 & 398 & $\begin{array}{l}281 \cdot \\
398 \\
34 .\end{array}$ & $\begin{array}{l}365 . \\
396 \\
300 .\end{array}$ & 20 & & .03 & 2 & · & 21 & 107 \\
\hline 9 & Gugars & Nothe & 1324.66 & 113639 & 308 & .302 & 200 & & 68 & 35.2 & 988 & Pam & 2010 & 265 & 265 & $\begin{array}{l}262 \\
290 .\end{array}$ & 21 & 48 & . & 15 & $\cdot$ & 12 & 88 \\
\hline 10 & Fwa & Nothy & 13217 & 1247.81 & 301 & 0.4 & 300 & 1900 & 6.4 & 389 & 891 & Pras & 2010 & 306 & $\begin{array}{l}306 \\
303 .\end{array}$ & $\begin{array}{l}302 \\
343 .\end{array}$ & 18 & 24 & 1.4 & . & 0.6 & 12 & 66 \\
\hline 11 & & Wobhe & 1320.16 & 1337.99 & 232 & 1 & 150 & 100 & 69 & 37.8 & 119 & 0.7 & 2010 & 400 & $\begin{array}{l}361 \\
699 .\end{array}$ & 388 & 26 & . & 1 & & 0.7 & 15 & 38 \\
\hline & & & 1304.63 & 130629 & 290 & 03 & 200 & 400 & 6.6 & 40 & 998 & 0.4 & 2010 & 321 & 321 & 306318 & $\$$ & 10 & 16 & . & 0.6 & 12 & 22 \\
\hline Arerse & & & & & .10 & & & & & & & & & & & & & 0.1 & & 14 & & & \\
\hline Total & & & & & & & & & & & 158 & & & & & & & & & & & & \\
\hline
\end{tabular}

